\title{
En syv måneder gammel jente med svette føtter
}

\author{
Bekymring rundt barnets vekst første leveår er en vanlig problemstilling. \\ Fastlege og helsestasjon forsøker med råd om kosthold og måltidsruti- \\ ner hvis barnet ellers utvikler seg normalt og viser tegn til trivsel. Imid- \\ lertid kan også blide barn ha underliggende sykdom, derfor er det rutine \\ å henvise barn med avflatende vekstkurve til den lokale barneavdelingen.
}

En syv måneder gammel jente ble henvist fra fastlege til utredning på grunn av avflatende vekstkurve og hyponatremi. Jenta var født til termin, etter ukomplisert svangerskap og fødsel, fødselsvekten var 3,6 kilo. Hun hadde fra to måneders alder ikke fulgt vektkurven sin og hadde falt fra 50-prosentilen til under 3-prosentilen.

Hun ble oppfattet som psykomotorisk aldersadekvat og var blid og aktiv. Hun hadde en frisk familie, var vaksinert uten påfallende reaksjoner på vaksinene, og nyfødtscreeningen hadde vært uten anmerkning. Moren hadde ammet henne fra fødselen og morsmelk var fortsatt hennes hovedernæring. I spedbarnsperioden hadde hun gulpet mye, men hun hadde ikke hatt betydelig diaré eller oppkast i forkant av innleggelsen.

Foreldrene fortalte at hun kunne lukte svette, spesielt fra føttene. Hun hadde vært en del syk med feber og luftveisinfeksjoner, alle gangene relativt kortvarig og ukomplisert. Avføringsprøve ved innleggelsen avslørte adenovirus. Røntgen thorax viste ingen fortetninger. Den kliniske undersøkelsen var normal. Blodtrykket var $100 / 65 \mathrm{~mm} \mathrm{Hg}$, temperaturen $37,2^{\circ} \mathrm{C}$.

Blodprøvene avslørte hypokalemisk metabolsk alkalose med hyponatremi og hypokloremi: $p H$ 7,49 (7,35-7,45), $p \mathrm{CO}_{2} 6,5 \mathrm{kPa}$ (4,7-6,0 kPa), baseoverskudd (BE) 11,9 $\mathrm{mmol} / \mathrm{l}(-3-+3 \mathrm{mmol} / \mathrm{l}), \mathrm{HCO}_{3} 36,6 \mathrm{mmol} / \mathrm{l}$ $(22,0-26,0 \mathrm{mmol} / \mathrm{l})$, natrium $128 \mathrm{mmol} / \mathrm{l}$ (137- $145 \mathrm{mmol} / \mathrm{l})$, kalium 3,1 mmol// $13,6-4,6$ $\mathrm{mmol} / \mathrm{l})$, klor $82 \mathrm{mmol} / \mathrm{l}(98-107 \mathrm{mmol} / \mathrm{l})$. Hun fikk tilskudd av natriumklorid og kaliumklorid og mat via nasogastrisk sonde.

Det er viktig å utelukke endokrine årsaker til hyponatremi hos spedbarn. $\AA$ overse slike kan ha fatale konsekvenser. Mineralkortikoidet aldosteron, som produseres i binyrebarken og har egne reseptorer for natriumregulering i nyrenes samlerør, er essensielt for regulering av saltbalansen. Et overskudd av aldosteron fører til økt resorpsjon av natrium $\mathrm{i}$ bytte for kalium, som skilles ut via urinen.

Gjennom kompliserte mekanismer fører vedvarende hypokalemi til økt resorpsjon av bikarbonat og utskilling av syre. Hyperaldosteronisme er derfor assosiert med hypo- kalemisk metabolsk alkalose og hypertensjon (1). På grunn av ledsagende væskeretensjon vil dette natriumoverskuddet vanligvis ikke være synlig i blodprøver. Sjeldne tilstander som varianter av kongenitt binyrebarkhyperplasi $(\mathrm{CAH})$ (forårsaket av 11 $\beta$-hydroksylase- eller $17 \alpha$-hydroksylasedefekter) og Liddles syndrom (uhemmet reopptak av natrium i nyrenes samlerør) er assosiert med hypokalemisk metabolsk alkalose og saltretensjon som kan debutere i spedbarnsalder.

Endokrinologisk betinget hyponatremi er som regel assosiert med metabolsk acidose og hyperkalemi, eksempler er klassisk kongenitt binyrebarkhyperplasi (med 21-hydroksylasedefekt), hypoaldosteronisme, pseudohypoaldosteronisme type I og type II og transient pseudohypoaldosteronisme (2).

Endokrinologisk utredning viste helt normale verdier: glukose 5,2 $\mathrm{mmol} / \mathrm{l}$, kortisol $\mathrm{kl}$ 0800 og kl 2000 henholdsvis $393 \mathrm{nmol} / \mathrm{l} \mathrm{og}$ $444 \mathrm{nmol} / \mathrm{l}$ (28-938 nmol/l - hos barn under to år forventes ikke døgnvariasjon av kortisol som hos større barn og voksne), adrenokortikotropt hormon (ACTH) kl 0800 og kl 2000 henholdsvis 2,08 pmol/log 3,13 pmol// (2-11 $\mathrm{pmol} / \mathrm{ll}$, thyreoideastimulerende hormon (TSH) 2,03 mU/l (1,1-8,2 mU/l) og fritt T4 18 $\mathrm{pmol} / \mathrm{l}(9,2-25,3 \mathrm{pmol} / \mathrm{ll}$.

Aldosteron- og reninaktivitet var på dette tidspunkt ikke avklart. Ultralyd og CT av nyrer og binyrer viste morfologisk normale organer. Til tross for adekvat ernæring og tilskudd av natriumklorid og kaliumklorid tok det en uke å normalisere serumverdiene.

Metabolsk alkalose sammen med saltmangel gjorde at nyresykdom kunne mistenkes. Ved nyresykdommen Bartters syndrom er det en defekt i resorpsjon av klor i nyrenes samlerør som fører til salttap i urinen, hyponatremi og hypokalemisk metabolsk alkalose. Salttapet fører til sekundær hyperaldosteronisme og økt reninaktivitet, blodtrykket er imidlertid vanligvis normalt. Bartters syndrom, alle med recessiv arvegang. Ved antenatalt Bartters syndrom er det symptomer allerede in utero, med polyhydramnion, prematur fødsel og et livstruende forløp
Minst fem genmutasjoner er involvert i

\author{
Ann Christin Gjerstad \\ ancgje@ous-hf.no \\ Barneavdelingen \\ Oslo universitetssykehus \\ Olav Trond Storrøsten \\ Norsk senter for cystisk fibrose \\ Oslo universitetssykehus \\ Egil Bakkheim \\ Norsk senter for cystisk fibrose \\ Oslo universitetssykehus \\ Kai Handeland \\ Sentrum Legekontor \\ Drammen \\ Hans-Jacob Bangstad \\ Barneavdelingen \\ Oslo universitetssykehus
}

Engelsk oversettelse på www.tidsskriftet.no 
på grunn av massivt salt- og væsketap, hyperkalsiuri og utvikling av nefrokalsinose. Klassisk Bartters syndrom debuterer i småbarnsalderen med mistrivsel (failure to thrive), hypokalemisk metabolsk alkalose, polyuri og salttap i urin.

Det var tatt urinprøve med tanke på elektrolyttap $i$ urinen før jenta fikk salttilskudd. Urinen hadde normalt elektrolyttinnhold, tatt $i$ betraktning lave serumverdier for de samme elektrolyttene ( $u$-natrium $<20 \mathrm{mmol} / \mathrm{l}, \mathrm{u}-\mathrm{klo}$ rid $<20 \mathrm{mmol} / \mathrm{l}$, u-kalsium 1,47 mmol/l, u-kalium $22 \mathrm{mmol} / \mathrm{ll}$. Urinen ble kontrollert igjen etter noen dager og viste fremdeles lavt innhold av salter.

Ingen av de endokrine eller nefrologiske tilstandene vi kjente til, kunne forklare den vedvarende metabolske alkalosen og det manglende salttapet i urinen. Bartters syndrom gir en metabolsk hypokalemisk alkalose, men salttap i urinen er obligat. Salttap via gastrointestinaltractus var også lite sannsynlig, da hun ikke hadde voldsom oppkast eller diaré

For å utelukke malabsorpsjon ble det tatt elastase $i$ avføringen, som viste normal verdi - den var > $500 \mathrm{ug} / \mathrm{g}$ (> $200 \mathrm{ug} / \mathrm{g}$ ).

Ved nyfødtscreeningen hadde alt vært normalt, og på grunn av normal elastase var det ikke mistanke om pancreassvikt. Kunne foreldrenes opplysninger om at jenta ofte luktet svette, likevel ha relevans?

Svettetest med måling av konduktans var patologisk: 69-73 mmol/l, men det var feilmelding på apparatet. Gentest viste sekvensvarianter i CFTR-genet i p.F508del og p.R117C i TRANS, som er forenlig med fenotypisk cystisk fibrose med bevart pancreasfunksjon. Det ble gjort en ny svettetest med spesifikk måling av klorid i svetten, som var $28 \mathrm{mmol} / \mathrm{l}$ og $38 \mathrm{mmol} / \mathrm{l}$, middelverdi 33 $\mathrm{mmol} / \mathrm{l} /<29 \mathrm{mmol} / \mathrm{l}$ normal, 30-59 mmol/l usikker, $\geq 60 \mathrm{mmol} /$ l patologisk).

En retrospektiv gjennomgang av barnets nyfødtscreening viste immunreaktivt trypsinogen (IRT) 39,5 ng/ml, dvs. normalverdi. etterkant kom det også svar angående aldosteron- og reninaktivitet - renin > 117,2 $\mathrm{nmol} / \mathrm{l} / \mathrm{t} \quad<28,5 \mathrm{nmol} / \mathrm{l} / \mathrm{t}$, personlig meddelelse, Hormonlaboratoriet, Aker) og aldosteron $2740 \mathrm{pmol} / \mathrm{l}(164-2929 \mathrm{pmol} / \mathrm{l})$ (3). Nyfødtscreeningen av barnet hadde vært normal med tanke på cystisk fibrose, allikevel ble altså sykdommen påvist etter gentesting, svettetest og ut fra sykehistorien.

\section{Diskusjon}

Hyponatremi er ikke uvanlig hos barn under ett år ved infeksjonssykdom, delvis på grunn av lite natrium i morsmelk/morsmelkerstatning. I tillegg tapes salter via svette, slim, oppkast eller diaré. Bedring av respirasjonsbesvær, bedre ernæring og behandling av den tilgrunnliggende infeksjonen bedrer ofte hyponatremien uten at det er nødvendig med andre tiltak. Jentas blodprøver viste hypokalemisk metabolsk alkalose med hyponatremi og hypokloremi. Spesielt ved kraftig oppkast ses det hyppig metabolsk alkalose hos barn. Pylorusstenose, for barneleger den klassiske hypokloremiske alkalosen, var svært lite sannsynlig fordi hun var over seks måneder og fordi det ikke hadde vært sprutbrekninger.

Pseudo-Bartters syndrom er en tilstand som imiterer klassisk Bartters syndrom med hypokalemisk metabolsk alkalose, men der det ikke er patologiske nyretubuli og dermed ikke renalt salttap. Ved mistanke om pseudoBartters syndrom er det viktig å undersøke for å finne andre årsaker til metabolsk derangering. Listen over årsaker til pseudo-Bartters syndrom inneholder kloridtap i avføringen, kloridtap i mageinnhold (sykliske brekninger) og kloridtap via huden (cystisk fibrose).

Pseudo-Bartters syndrom er assosiert med cystisk fibrose. Småbarn som er brysternært eller som får morsmelkerstatning, er særlig utsatt for hyponatremi på grunn av lavt saltinnhold i melken. I tillegg kan feber, årstid og forsinket cystisk fibrose-diagnose bidra til utvikling av pseudo-Bartters syndrom. I Spania er det vist en forekomst av pseudo-Bartters syndrom hos barn med cystisk fibrose på $16,8 \%$ (4). Det er grunn til å tro at tilstanden kan være underdiagnostisert hos barn med cystisk fibrose i Norge. Søreuropeiske land har imidlertid et annet klima, der kan varmen bidra til utvikling av tilstanden.

Hos friske mennesker vil det ved økt svetting være en tilpasning av svettens innhold av natrium og klor, men hos personer med cystisk fibrose kan økt svetting føre til eksessivt salttap og vaskulær kollaps (5). Tapet av natrium og klor fører til hypovolemi ekstracellulært, noe som igjen fører til reninaktivering i det jukstaglomulære apparat i glomeruli og derav aktivering av renin-angiotensinaldosteron-systemet (RAS) og sekundær hyperaldosteronisme. Det økte aldosteronnivået vil føre til økt kaliumtap både i svetten og i urinen og derigjennom hypokalemi (5). Pasientens høye reninaktivitet og normale aldosteronnivå kan kanskje forklares av at lavt serum-kalium kan nedregulere aldosteronfrigjøringen (6).

Det er viktig å ta hyponatremi hos barn med cystisk fibrose alvorlig, da normalisering av natriumkloridnivået i blodet gjennom tilskudd kan bremse reninaktiviteten. Det er også vist at barn med cystisk fibrose kan ha normalt serum-natrium, men allikevel aktivering av renin-angiotensin-aldosteron-systemet som uttrykk for natriumunderskudd og hypovolemi (7).

Natrium er i barnets første leveår en viktig vekstfaktor, og hyponatremi er sannsynligvis et sent tegn på natriumunderskudd hos barn med cystisk fibrose. Forebyggende ekstra salttilskudd per os er etter første leveår ikke en generell anbefaling ved cystisk fibrose i Norge. Det er imidlertid anbefalt å gi ekstra salttilskudd ved økt svetting. I tillegg skal hyponatremi ved pseudo-Bartters syndrom hos barn med cystisk fibrose også korrigeres aktivt (7). Spotnatriumverdier i urinen $<20 \mathrm{mmol} / \mathrm{l}$ og hyponatremi i serum indikerer en klinisk relevant mangel på natrium.

1.3. 2012 ble nyfødtscreeningen her i landet utvidet fra to til 23 tilstander, inkludert cystisk fibrose. I Norge består screeningen for cystisk fibrose av måling av immunreaktivt trypsinogen (IRT) i blod tatt ved hælstikk i tidsrommet 60-72 t etter fødselen. Grenseverdien for positiv prøve for cystisk fibrose var på det tidspunktet vår pasient ble testet en IRT-verdi $>59,5 \mathrm{ng} / \mathrm{ml}$. Alle blodprøver med forhøyet IRT-verdi blir så testet for mutasjoner i CFTR-genet (cystisk fibrose-transmembranregulator-genet). Barn med forhøyet IRT-nivå og to sykdomsgivende $C F T R$-mutasjoner blir meldt som screeningpositive og går videre til diagnostikk for cystisk fibrose ved Oslo universitetssykehus eller Haukeland universitetssykehus (8).

CFTR-genet sitter på kromosom $7 \mathrm{og}$ koder for CFTR-proteinet, som uttrykkes på epiteliale celler hovedsakelig i eksokrine kjertler. Dette CFTR-proteinet fungerer vesentlig som klorkanal, men hemmer også epitelial natriumtransport og kalsiumaktiverte klorkanaler og er involvert i bikarbonat-klor-utvekslingen. Defekten i bikarbonatsekresjon fører til nedsatt løselighet av glykoproteiner i sekret og derav seigt sekret.

Eksokrine kjertler finnes blant annet på huden og i tarm, bukspyttkjertel, lunger, galleganger og kjønnsorganer. I lungene fører seigt slim til obstruksjon, noe som disponerer for infeksjon og inflammasjon som over tid gir vevsdestruksjon og fibrose.

I bukspyttkjertelen fører også seigt sekret til obstruksjon av de eksokrine utførselsgangene, noe som på grunn av enzymmangel gir nedsatt nedbrytning av fett og dermed underernæring. 85-90\% av barn med cystisk fibrose utvikler pancreassvikt. Over tid kan pasienten også utvikle en cystisk fibrose-relatert type diabetes mellitus (CFRD). Gallegangene kan også stoppes til av det seige sekretet, og med økt inflammasjon kan dette over tid føre til biliær cirrhose hos større barn og ungdom. 
I tarmen gir det seige sekretet påvirket motilitet, slik at pasienten både kan ha diaré og forstoppelse, og hos den nyfødte er mekoniumileus så godt som patognomonisk for cystisk fibrose.

Infertilitet er svært vanlig hos menn med tilstanden, delvis på grunn av dårlig utviklet vas deferens. De fleste kvinner er fertile, og det er mer usikkert hvordan kvinners fertilitet er påvirket.

Overlevelsen er bedret kraftig de siste årene på grunn av tidlig diagnose, aktiv behandling, nye medisiner og lungetransplantasjoner.

Cystisk fibrose er en progredierende multiorgansykdom, men den forventede levealder er nå på over 40 år (9). Insidensen i Norge er anslått til 1 per 5600 nyfødte. Arvegangen er autosomalt recessiv, og ca. $3 \%$ av befolkningen her i landet er bærere av sykdommen. Det er i Norge i dag i overkant av 300 personer med cystisk fibrose, som er den hyppigst forekommende alvorlige autosomalt arvelige recessive sykdommen hos oss.

Før dette barnet fikk diagnosen, var det ikke rapportert om barn med falskt negativt screeningresultat for cystisk fibrose i Norge. Omtrent 120000 nyfødte her i landet deltok i nyfødtscreeningen i løpet av de to første årene. 25 barn har i løpet av disse to årene hatt en positiv nyfødtscreening for tilstanden med bakgrunn i forhøyet IRT-nivå ved screeningtidspunktet og to CFTR-mutasjoner. Det er kun meldt om enkelttilfeller av falskt negativt screeningresultat på grunn av lavt IRT-nivå internasjonalt (10-12). Ingen av de rapporterte barna hadde mekoniumileus, som er kjent for å ha sammenheng med lave IRT-verdier (13). Alle nyfødte med mekoniumileus bør derfor gentestes med tanke på cystisk fibrose.

Sensitiviteten av screeningen ved bruk av IRT-måling og multiple CFTR-mutasjoner er beregnet å kunne ligge så høyt som 95,8-96,2 \% $(10,14)$. Allikevel må man alltid ta høyde for at screening ikke avdekker alle syke. Det er viktig at leger som er utdannet etter at cystisk fibrose ble inkludert $\mathrm{i}$ screeningen, er oppmerksomme på typiske symptomer ved tilstanden. I tillegg kommer det faktum at mange barn som vokser opp i Norge, kommer fra land uten screeningprogram.

Ved hyppige luftveisinfeksjoner, vedvarende infiltrater på røntgen thorax og bronkiektasier er cystisk fibrose lett å huske på.
Imidlertid er det også mange andre tegn som skal gi mistanke om tilstanden: mekoniumileus, kolestase, steatoré (pga. pancreassvikt), mangel på fettløselige vitaminer, residiverende eller kronisk pankreatitt, avflatende vekst (failure to thrive), kalsifiseringer $\mathrm{i} a b-$ domen eller scrotum, nasal polypose, kronisk pansinusitt, pseudomonas i luftveissekret, manglende vas deferens, saltsmakende hud og, som hos denne pasienten, hypokloremisk alkalose uten salttap i urinen (9).

Denne piken fikk en rask diagnose gjennom systematisk utredning på tross av negativ nyfødtscreening. Innleggende lege husket å måle elektrolytter i urinen før barnet fikk substitusjonsbehandling, hvilket forenklet og forkortet utredningen. Tilfellet illustrerer at det fortsatt er viktig å huske på cystisk fibrose ved symptomer forenlig med tilstanden også hos barn som der det er normale resultater ved nyfødtscreeningen.

\section{Barnets foreldre har gitt samtykke til at artikkelen} blir publisert.

\section{Ann Christin Gjerstad (f. 1968)}

er ph.d., spesialist i barnesykdommer og overlege.

Forfatter har fylt ut ICMJE-skjemaet og oppgir ingen interessekonflikter.

\section{Olav Trond Storrøsten (f. 1948)}

er cand.med., spesialist i barnesykdommer. overlege og seksjonsleder.

Forfatter har fylt ut ICMJE-skjemaet og oppgir ingen interessekonflikter.

\section{Egil Bakkeheim (f. 1968)}

er ph.d., spesialist i barnesykdommer og overlege.

Forfatter har fylt ut ICMJE-skjemaet og oppgir ingen interessekonflikter.

\section{Kai Samson Handeland (f. 1964)}

er barnelege og driver egen praksis i Drammen.

Forfatter har fylt ut ICMJE-skjemaet og oppgir ingen interessekonflikter.

\section{Hans-Jacob Bangstad (f. 1949)}

er dr.med., professor II og assisterende avdelingsleder.

Forfatter har fylt ut ICMJE-skjemaet og oppgir

ingen interessekonflikter.
Litteratur

1. Galla JH. Metabolic alkalosis. J Am Soc Nephrol 2000: 11: 369-75

2. Lindenskov PHH, Rønnestad A, Skari H. Et spedbarns mistrivsel endte med døden. Tidsskr Nor Legeforen 2012; 132: 1964-7.

3. Dillon MJ. Ryness JM. Plasma renin activity and aldosterone concentration in children. BMJ 1975; 4: $316-9$

4. Ballestero Y, Hernandez MI, Rojo P et al. Hyponatremic dehydration as a presentation of cystic fibrosis. Pediatr Emerg Care 2006; 22: 725-7.

5. Marah MA. Pseudo-Bartter as an initial presentation of cystic fibrosis. A case report and review of the literature. East Mediterr Health J 2010; 16 : 699-701.

6. Simopoulos AP, Lapey A, Boat TF et al. The reninangiotensin-aldosterone system in patients with cystic fibrosis of the pancreas. Pediatr Res 1971; 5: 626-32

7. Coates AJ, Crofton PM, Marshall T. Evaluation of salt supplementation in CF infants. J Cyst Fibros 2009; 8: 382-5.

8. Lundman E, Gaup HJ, Bakkeheim E et al. Implementation of newborn screening for cystic fibrosis in Norway. Results from the first three years. J Cyst Fibros 2016; 15: 318-24

9. O'Sullivan BP, Freedman SD. Cystic fibrosis. Lancet 2009; 373: 1891-904.

10. Massie RJ, Curnow L, Glazner J et al. Lessons learned from 20 years of newborn screening for cystic fibrosis. Med J Aust 2012; 196: 67-70.

11. Dunn CT, Skrypek MM, Powers AL et al. The need for vigilance: the case of a false-negative newborn screen for cystic fibrosis. Pediatrics 2011; 128: e446-9.

12. Comeau AM, Parad RB, Dorkin HL et al. Population-based newborn screening for genetic disorders when multiple mutation DNA testing is incorporated: a cystic fibrosis newborn screening model demonstrating increased sensitivity but more carrier detections. Pediatrics 2004; 113: 1573-81.

13. Rusakow LS, Abman SH, Sokol RJ et al. Immunoreactive trypsinogen levels in infants with cystic fibrosis complicated by meconium ileus. Screening 1993; 2 : $13-7$.

14. Kloosterboer M, Hoffman G, Rock M et al. Clarification of laboratory and clinical variables that influence cystic fibrosis newborn screening with initial analysis of immunoreactive trypsinogen. Pediatrics 2009; 123: e338-46.

Mottatt 22.12. 2015, første revisjon innsendt 27.5 2016, godkjent 23.6. 2016. Redaktør: Martine Rostadmo. 